\title{
The strategic implantation of energy management in a multinational enterprise
}

\author{
J. González de la Viuda ${ }^{1}$, V. Romero Arauzo ${ }^{2}$ \\ ${ }^{1}$ Department of electrical engineering,Escuela Politecnica Superior. Burgos University \\ Avd. de Cantabria s/n 09004 Burgos (Spain) \\ Phone: 0034947259347, e-mail: jgv@ubu.es \\ ${ }^{2}$ L'OREAL, Products Capilares \\ Polígono Industrial de Villalonquejar, Burgos 0034947473209
}

\begin{abstract}
This work presents the actions taken jointly by the firm L'Oreal and the department of Electrical Engineering of the University of Burgos, which initiated an energy management strategy with the ultimate objective of reducing energy consumption. Save electricity is possible.
\end{abstract}

\section{Key words}

Energy management, renewable energy, solar energy, electrical consumption, energy-saving strategies.

\section{Objectives}

The proposed objectives are:

- To map out the global distribution of energy consumption.

- To identify potential improvements.

- To study the profitability of the proposed improvements from both an energetic and an economic point of view.

- To anticipate energy consumption.

- To set up awareness-raising programmes for staff at the plant.

By achieving these objectives, the firm will become more competitive thanks to improved energy efficiency. [1] In order to reach these objectives, a number of initial problems have first to be overcome, due to the industrial plant being over 30-years old, the absence of measurement devices and to the exponential growth of the factory over recent years.

\section{Methodology}

The following plan was proposed to carry out the project:

1. Diagnosis of energy consumption at the industrial plant. Data gathering and data management.

2. Installation of renewable energies.

3. Improvement and modification of the principal energy consumers. Technical and economic viability studies.

4. Energy-saving and awareness-raising strategies among workers.

\section{Multinational enterprise}

The object of this study is the multinational L'Oreal Group, which forms part of the cosmetics sector. Founded in 1907 by the chemist, Eugéne Schueller, it currently employs 50,500 workers in 43 industrial production plants and has a presence in 130 countries.

The factory under study is located in Burgos, has a staff of 600 employees and manufactures some 250 million units on an annual basis.

\section{Renewable energies}

The factory has a solar thermal installation for hot water that provides 2,000 litres of water at $55^{\circ} \mathrm{C}$. It is an old installation, which has collectors whose performance is low compared to those on the market at present.

It also has a solar photovoltaic installation of $100 \mathrm{kWp}$ made up of panels that are fixed (45\%) and mounted on solar followers (55\%). The installation is made up of 252 panels (sw 220) on the two solar followers and 214 fixed panels (sw 210) arranged in 4 rows.

\section{Measurement equipment and data collection management systems}

"Power Logic" by Merlin Gerin is used for data management of electrical consumption at the plant, with the following layout.

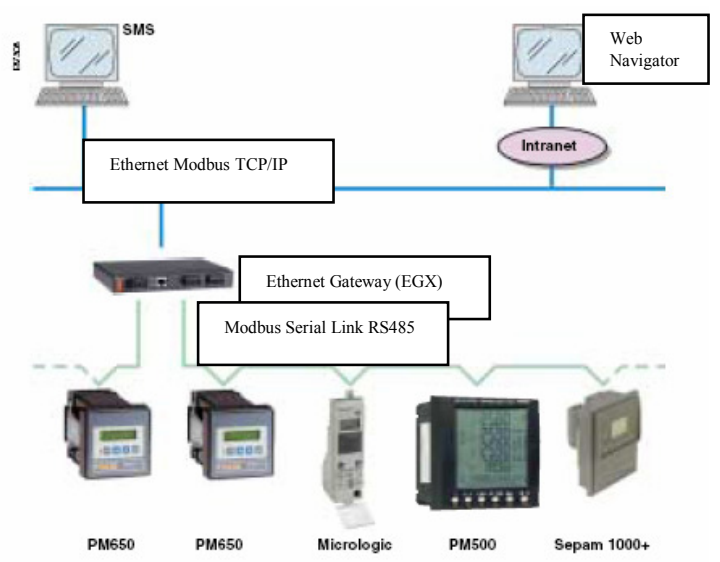

Fig. 1. Plan of electrical data intake 


\section{Energetic balance of the plant. 2006}

The followings tables show the most significant energetic data for 2006, covering the electrical energy generated by the solar panels and gas and electricity consumption.

Consumption of $1 \mathrm{kWh}$ of energy is considered equivalent to $211 \mathrm{gr}$ of $\mathrm{CO}_{2}$ [2]

TABLE I.- Photovoltaic solar cell generation on a monthly basis

\begin{tabular}{|l|c|c|}
\hline \multicolumn{1}{|c|}{ Month } & $\begin{array}{c}\text { Energy generated } \\
(\mathrm{kWh})\end{array}$ & $\begin{array}{c}\mathrm{CO}_{2} \text { not emitted } \\
(\mathrm{Tn})\end{array}$ \\
\hline January & $7,200.56$ & 1.52 \\
\hline February & $9,291.05$ & 1.96 \\
\hline March & $14,435.41$ & 3.05 \\
\hline April & $15,861.15$ & 3.35 \\
\hline May & $17,589.95$ & 3.71 \\
\hline June & $18,847.56$ & 3.98 \\
\hline July & $21,155.94$ & 4.46 \\
\hline August & $20,607.32$ & 4.35 \\
\hline September & $18,349.82$ & 3.87 \\
\hline October & $12,858.15$ & 2.71 \\
\hline November & $9,091.95$ & 1.92 \\
\hline December & $6,617.66$ & 1.40 \\
\hline Year: 2006 & $171,113.00$ & 36.10 \\
\hline
\end{tabular}

TABLE II.- Electrical consumption by principal receptors

\begin{tabular}{|l|c|c|c|}
\hline \multicolumn{4}{|c|}{ ELECTRICAL CONSUMPTON 2006 } \\
\hline & $\begin{array}{c}2006 \\
\text { Consumpti } \\
\text { on (kWh) }\end{array}$ & $\begin{array}{c}\text { \% of total } \\
\text { consumptio } \\
\text { n }\end{array}$ & $\begin{array}{c}\text { Co2 } \\
\text { Emissions } \\
\text { (Tn) }\end{array}$ \\
\hline Lighting & $1,881,202$ & 17,6 & 396.93 \\
\hline Compressors & $2,720,688$ & 25.4 & 574.07 \\
\hline Battery charging & 157,092 & 1.5 & 33.15 \\
\hline $\begin{array}{l}\text { Manufacturing } \\
\text { (PU1) }\end{array}$ & 411,600 & 3.8 & 86.85 \\
\hline Packaging (PU1) & 732,960 & 6.8 & 154.65 \\
\hline $\begin{array}{l}\text { Manufacturing } \\
\text { (PU2) }\end{array}$ & 318,000 & 3.0 & 67.10 \\
\hline Packaging (PU2) & 553,320 & 5.2 & 116.75 \\
\hline $\begin{array}{l}\text { Manufacturing } \\
\text { (PU3) }\end{array}$ & 342,462 & 3.2 & 72.26 \\
\hline Packaging (PU3) & 738,480 & 6.9 & 155.82 \\
\hline Hot water (PU3) & 65,000 & 0.6 & 13.72 \\
\hline Air conditioning & 987,110 & 9.2 & 208.28 \\
\hline $\begin{array}{l}\text { Wastewater } \\
\text { treatment plant }\end{array}$ & 166,390 & 1.6 & 35.11 \\
\hline Restaurant & 108,486 & 1.0 & 22.89 \\
\hline Creams & 414,270 & 3.9 & 87.41 \\
\hline Ice storage & 563,808 & 5.3 & 118.96 \\
\hline $\begin{array}{l}\text { U.P.S. } \\
\text { (Uninterrupted } \\
\text { Power Supply) }\end{array}$ & 215,889 & 2.0 & 45.55 \\
\hline Osmosis waters & 237,317 & 2.2 & 50.07 \\
\hline Fire systems & 20,880 & 0.2 & 4.41 \\
\hline Transformers & 72,000 & 0.7 & 15.19 \\
\hline
\end{tabular}

TABLE III.- Consumption of gas on a monthly basis by heating and industrial production

\begin{tabular}{|l|r|r|r|}
\hline \multicolumn{4}{|c|}{ GAS CONSUMPTION } \\
\hline & $\begin{array}{c}\text { miles } \\
\mathrm{kWh}\end{array}$ & $\begin{array}{c}\text { Heating } \\
\text { miles } \\
\mathrm{kWh}\end{array}$ & $\begin{array}{c}\text { Producti } \\
\text { on miles } \\
\mathrm{kWh}\end{array}$ \\
\hline January & 1936.0 & 945.2 & 990.8 \\
\hline February & 1840.0 & 849.2 & 990.8 \\
\hline March & 1773.0 & 797.7 & 975.3 \\
\hline April & 994.0 & 185.6 & 808.4 \\
\hline May & 1051.0 & 80.9 & 970.1 \\
\hline June & 800.0 & 34.6 & 765.4 \\
\hline July & 826.0 & 0.0 & 826.0 \\
\hline August & 824.0 & 0.0 & 824.0 \\
\hline September & 865.0 & 0.0 & 865.0 \\
\hline October & 888.0 & 31.2 & 856.8 \\
\hline November & 1172.0 & 189.7 & 982.3 \\
\hline December & 1186.0 & 590.6 & 595.4 \\
\hline
\end{tabular}

As may be seen in Table II, the highest electrical consumption corresponds to lighting and compressors. Naturally, the solutions put forward to reduce energetic consumption will concern these two receptors, and will also make improvements to the heating installation.

\section{Economic viability of the proposed improvements}

Having undertaken the energetic audit and identified the receptors that consume most energy, three improvements techniques were proposed:

Installation of compressed-air compressors The present situation is that output pressure is $11 \mathrm{bar}$, the diameter of the piping that feeds the furthest point is 2 " (100 metres) and the output pressure provided at that point is 8 bar. The conclusion is that a high loss of charge occurs along the tubes.

In the future, the plan is for the outlet pressure of the compressors to be 8.5 bar, and the pipe diameters will be widened to 4 " such that the estimated loss-ofcharge will be 0.5 bar.

This improvement will result in the reduction of energetic consumption by $20 \%$ in the compressed air system, as well as improving the performance of the compressors, reducing losses in the piping, reducing the working hours of the compressors, etc.

The planned investment amounts to 19,710 euros.

The economic viability of the replacement piping has a return-on-investment period of 6.1 months.

Lighting installation. In order to reduce the energetic consumption of lighting, it is proposed to substitute the existing magnetic ballasts for electronic ones, to use photocells in the zones where natural light exists and to install movement sensors. [3]

The consequences of these improvements will be a $25 \%$ reduction in consumption.

A trial project involving the substitution of 72 fluorescent screens has already achieved energy savings of $20 \%$.

The planned investment amounts to 36,302 euros. 
The economic viability of these three measures has a return-on-investment period of 19 months.

Heating installation. The measures to improve the heating system will consist of the use of economizers at the steam outlets, transferring heat to the entire steam network and enlarging the steam piping section.

The planned investment amounts to 42,500 euros.

The economic viability of these measures has a return-on-investment period of 2.1 years.

\section{Strategy of the L'OREAL multinational group}

The principal strategy of the Group is to promote interfactory competition, in such a way as to create internal competitiveness that will help to reduce energetic consumption.

To that end, it is proposed:

- To set concrete objectives for the different production units.

- To compare the energetic consumption of different industrial plants.

- To disseminate the results of the different factories at a global level.

Secondly, there is a need to raise worker awareness of energy consumption. Training talks will be given in order to raise awareness of staff at the factory so that they are conscious of the different energetic consumptions at the plant.

Likewise, information sheets will be made available at different work stations providing data on $\mathrm{CO} 2$ emissions, energy consumed and the cost in euros. An example of the consumption of compressed air pistol is shown below.

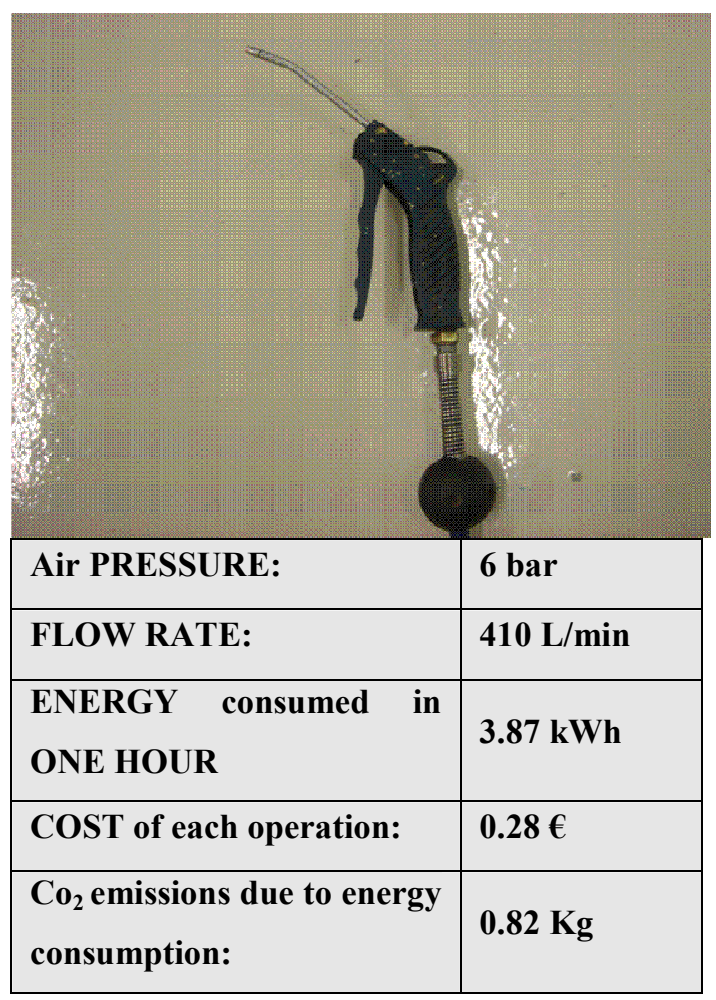

Fig. 2. Information sheet for compressed-air pistol.

\section{Conclusions}

- Energy consumption for lighting and for air compressors is significant.

- Until an energetic balance is achieved, it will be difficult to propose sound technical solutions to reduce consumption.

- Energetic consumption can be reduced through "awareness-raising" and "information" strategies, expending little effort.

- $\quad$ Energy saving is possible.

- THE BEST kWh IS THE ONE THAT IS NOT CONSUMED.

\section{Acknowledgements}

The authors are grateful to the Departments of Maintenance, Safety, Environment and New Technical Projects for Capillary Products at L'OREAL, Burgos.

\section{References}

[1] IDAE, Instituto para la diversificación y ahorro de la energía, bulletin $\mathrm{n}^{\circ} 5$. (2003).

[2] Iberdrola, Results 2006.

[3] CADDET, Centre for the analysis and dissemination of demonstrated energy technologies. (1995). 